\title{
Centros Integrados de Educação Pública: uma nova escola
}

\author{
SECRETARIA DE ESTADO DB EDUCACAAOO \\ DO RIO DE JANEIRO
}
A se implantar uma nova escola no estado do Rio de Janeiro - os CIEPs (Centros Integrados de Educação Pública) -, abriu-
se um novo caminho para a educação pública brasileira.

A escola de vários turnos já foi suficientemente testada na história da educação pública deste país e o que tem produzido é a repetência continuada que traz, como conseqüência, a redução das vagas disponíveis ou a evasão, alimentando-se o crescente número de analfabetos. " $O$ censo nacional de 1970 nos revela que entre os jovens de 14 anos de idade uma quarta parte $(24,3 \%)$ não sabia ler e escrever. Esta juventude analfabeta era de $42 \%$ nas zonas rurais e de $10 \%$ na cidade. Finalmente, no último censo, em 1980 , a porcentagem subiu para $25,9 \%$ e o número absoluto elevou-se para 19 milhóes. Sáo esses os dados censitários dos analfabetos adultos no Brasil. Esses números e proporçōes tornam-se mais significativos se comparados com outros desempenhos educacionais. Enquanto o Brasil de 1980 conta com 19 milhóes de analfabetos adultos e com a porcentagem de 26\%, na Argentina é de 6\% em 1976 e, em Cuba, já em 1961, era de 3\%. A nossa inferioridade estatística reflete uma inferioridade efetiva no esforço por alfabetizar e na capacidade de alcançar esta meta elementar" (1).

Isto se visualiza nos dados abaixo

Brasil - Censos Nacionais: analfabetos com 15 anos e mais

$\begin{array}{lll}\text { 1950: } & 50,5 \% & 15,0 \text { milhŏes } \\ \text { 1960: } & 39,3 \% & 16,0 \text { milhóes } \\ \text { 1970: } & 33,0 \% & 18,0 \text { milhóes } \\ \text { 1980: } & 26,0 \% & 19,0 \text { milhöes }\end{array}$

Analfabetismo na América Latina

$\begin{array}{lll}\text { Cuba } & 1961 & 3 \% \\ \text { Costa Rica } & 1975 & 11 \% \\ \text { Argentina } & 1976 & 6 \% \\ \text { Uruguai } & 1978 & 10 \%\end{array}$


Podemos, assim, constatar que "não fomos capazes, até hoje, de criar uma escola pública honesta, adaptada às necessidades da população brasileira" (2). O fracasso educacional brasileiro "não se explica, obviamente, pela falta de escolas - elas aí estão, numerosíssimas - nem por falta de escolaridade, uma vez que estão repletas de alunos, sobretudo na primeira série, que absorve quase metade da matrícula. Muitos fatores contribuem para este fracasso, mas a razáo causal verdadeira não reside em nenhuma prática pedagógica. Reside, isto sim, na atitude das classes dominantes para com o nosso povo" (3).

Um dos motivos de nosso baixo rendimento escolar reside no fato de darmos à criança um atendimento em tempo exíguo. A escola de turno único abre um espaço à construção de uma escola pública verdadeiramente democrática que atenda aos interesses e necessidades das camadas mais pobres da população, a uma proposta pedagógica que se coadune com tais objetivos, buscando reverter a determinafão de que as crianças dessas camadas irão fracassar inevitavelmente, tanto em suas possibilidades acadêmicas quanto em seus acessos sociais.

Torna-se, então, clara a importância de incorporar à escola o universo cultural dos alunos, respeitar sua linguagem e as características da cultura produzida no meio em que vive, para que a vida possa se concretizar no cotidiano institucional e as novas vivências pedagógicas possam repercutir além do espaço escolar.

Nada mais antidemocrático do que tratar os diferentes como iguais. Daí a importância de uma diretriz metodológica que leve em conta o tempo próprio dos alunos, unificando os conteúdos - que devem ser essencializados no sentido de serem priorizados os que realmente possibilitem a apreensão e transformação da realidade - assim como as formas de apresentá-los, favorecendo a construção, pelos alunos, das ferramentas de análise teórica articuladas com o contexto de sua produção. Tal concepção é eminentemente interdisciplinar. Articulandose a lógica própria da produçáo do conhecimento e assumindo-se a alfabetização e a língua materna como elos integradores, cada disciplina trabalhará com o objetivo de ampliar o vocabulário do aluno, sistematizar a sua expressão oral e aprimorar a expressão escrita, de modo a atualizar seus universos lingüísticos e proporcionar-lhes a flexibilidade de raciocínio e consciência necessária a pensar e agir criticamente sobre a realidade sociocultural e política.

Uma proposta com tais objetivos terá que necessariamente repensar·a avaliação tal como vem sendo conduzida. A tarefa dos educadores envolvidos na construçáo dos CIEPs (Centros Integrados de Educação 


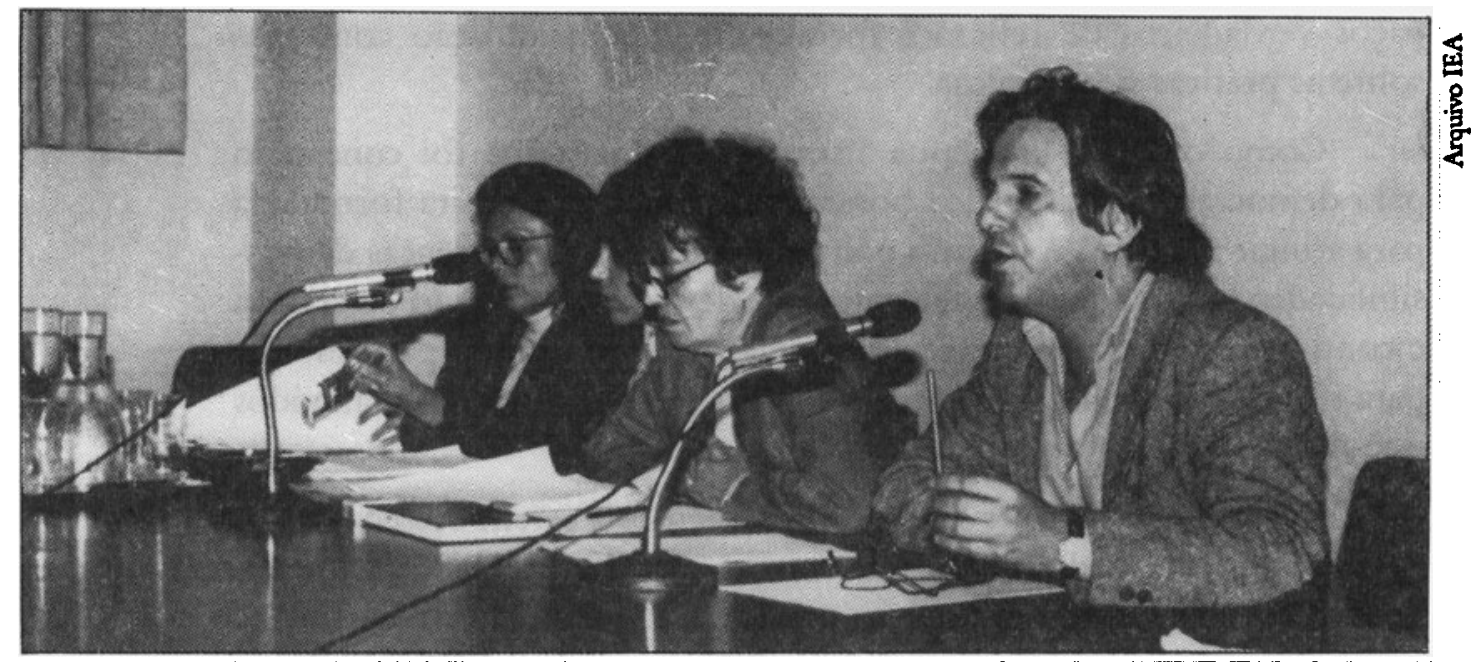

Paulo Sérgio de Castro Pinto Duarte, secretdrio-adjunto da secretaria de Estado de Educafáo do Rio de Janeiro, falou em outubro de 91 no IEA sobre "Educaçá e Cieps: Uma Avaliaçăo".

Pública) será a de transformar esse instrumento que tem sido utilizado como mecanismo de reproduçáo das classes sociais, na medida em que a escola avalia somente o que o aluno náo sabe (os padróes da cultura de classe dominante que ainda não adquiriu) e náo o que o aluno sabe (o que conseguiu acrescentar ao saber $\mathrm{e}$ às práticas que já dominava).

Se a avaliação passa a ser encarada como instrumento do aperfeiçoamento contínuo do trabalho pedagógico, cada aluno deve ter avaliado o seu crescimento continuamente, para ser atendido na medida de suas necessidades e possibilidades. Tal transformação não se dá apenas com iniciativas individuais. Torna-se necessário que, ao avaliar os alunos, o professor avalie também seu próprio trabalho, num esforço coletivo de todos os envolvidos na comunidade escolar e que, ao mesmo tempo, a totalidade da instituiçăo escolar seja permanentemente avaliada e questionada.

A açáo democratizadora da escola tem nos CIEPs (Centros Integrados de Educação Pública) espaço privilegiado para crescimento enquanto campo de estudos das relaçōes institucionais que aí se dão. Alternando-se drasticamente um dos elementos que compóem a estrutura das relaçōes na escola - o número de horas que os alunos nela permanecem -, afloram com maior nitidez as contradiçōes existentes nos papéis e funções de cada grupo ou segmento escolar, o jogo do poder no interior da instituição, nas relaçóes com todo o sistema social envolvente. Daí a necessidade de uma gestão cooperativa, que estimule a participaçáo de toda a comunidade escolar no sentido de superar a arbitrariedade e a centralizaçáo do poder na mão de poucos, criando-se es- 
paços verdadeiros de reflexão, formulação e reformulaçáo contínuas sobre as práticas pedagógicas.

Como o PEE (Programa Especial de Educaçáo) foi concebido para democratizar a escola, o horário integral é a proposta formulada para atingir este fim. A decisão política de atenuar as diferenças de possibilidades sociais, que sáo determinadas desde o nascimento da criança e continuam, inclusive, através da escola, intervindo no espaço escolar para reverter expectativas sociais, é determinante de todos os conteúdos que alicerçam este Programa.

Dessa forma, os acervos de conhecimentos a serem oferecidos aos alunos seráo veiculados através de formas variadas, de diversas linguagens e em momentos diferenciados. Seria impossível familiarizar as crianças ao livro, ao filme, ao teatro, a danças variadas, a músicas diversas, enfim, levá-las a alcançar a habilidade de domínio de códigos, que não são originalmente os dela, em quatro horas por dia.

Assim, a Sala de Leitura oferecerá uma gama de material impresso aos alunos que, individualmente, a ele não teriam acesso. $O$ vídeo levará ao cotidiano destes alunos uma linguagem, hoje, indispensável a nossa sociedade. O estudo dirigido buscará aprofundar os conhecimentos por áreas de preferências das crianças e possibilitará observar os diferentes ritmos de aprendizagem, como um deper de casa orientado. $O$ trabalho com esportes variados e com as diferentes formas de expressão artística tem nesse espaço importância fundamental, porque lida com diferentes canais de expressão do ser humano. A aquisiçáo de novos conhecimentos pelas crianças dar-se-á de forma bem mais fácil e dinâmica, se não dissociarmos a educação de seu contexto cultural. Esta integração, prevista pelo Programa Especial de Educação e que tem a Animaçáo Cultural como um de seus agentes, valoriza e leva para dentro da escola a cultura da comunidade a que os alunos pertencem.

A organização do tempo e do espaço de todos estes conhecimentos, nos CIEPs, tem como centro o aluno. Esta parece ser uma afirmação banal, pois seria muito simples transformar uma escola de dois turnos em turno único, multiplicando-se por dois a carga horária de cada disciplina ou atividade a ser oferecida. Se a escola em vários turnos já é um fracasso, teríamos este insucesso em dobro. Organizar o tempo e o espaço em funçáo do aluno não implica apenas em adotar novas medidas administrativas que o novo sistema vai requerer, mas, principalmente, em deixar à disposição dele sua possibilidade de decisão a respeito do tempo e do espaço escolar, a partir de uma prática e da discussáo coletiva da mesma. 
Ao se retomar a implantação dos CIEPs no estado do Rio de Janeiro, depois de quatro anos de abandono dos professores a sua própria sorte, mais do que nunca será necessário forjar uma vontade política que seja capaz de superar a descrença do magistério do Estado. E é esta vontade política que nos dá a certeza de que é possível recomeçar, coordenar o que já se pensou, já se conseguiu e já se deixou pelo meio da estrada. O CIEP será, entăo, uma construçáo coletiva daqueles que pensam a educaçáo e vivenciam a sua práxis. Tal retomada do PEE (Programa Especial de Educaçáo) no âmbito do estado do Rio de Janeiro se dá após quatro anos de deliberadas açóes de desativação e mesmo insidiosa destruição dos CIEPs promovidos pela administração anterior que deixou, ao mesmo tempo, todas as escolas, também de horário parcial, ao abandono e relegadas a iniciativas individuais. Todo esse tempo gerou um descrédito cada vez maior do professorado quanto a qualquer política educacional, de qualquer governo. Gerou, portanto, uma resistência. É a partir desses dados e com eles que nos propomos a retomar o Programa Especial de Educaçáo, em toda a sua natureza e firmeza de propósitos: uma escola onde o ensino deve ser orientado para a criaçáo e para a expressão e não para a recepşão passiva do conhecimento e a repetiçáo mecânica das informaçóes: alunos e professores, enquanto sujeitos de suas ações, integrando-se e estabelecendo um posicionamento crítico que permita repensar e reconstruir o mundo. Tarefa nada fácil, mas nem por isso impossível, se considerarmos que não há saber pronto e acabado, não há verdades definitivas.

Nesse quadro, convém explicitar cada um dos projetos que integram o PEE (Programa Especial de Educaçáo), no que concerne à proposta dos CIEPs.

\section{Sala de Leitura}

Fortalecida pela experiência de suas metas pedagógicas no contexto do estado e do município do Rio de Janeiro, a Sala de Leitura/TV/Nídeo retoma sua proposta, levando em consideraçăo a filosofia do PEE (Programa Especial de Educação), o conceito de leitura e o papel da Sala de Leitura.

Dentro desta proposta pedagógica, onde o ensino é orientado para o desenvolvimento do raciocínio lógico, do espírito crítico e da cidadania participativa, o domínio da linguagem oral e escrita é fundamental, não só como instrumento de comunicação e integração social, mas também como elemento de transformaçáo do mundo a partir da leitura crítica do mesmo.

"Se educar é preparar para a vida, despertar consciências, com- 
preender e transformar a realidade, então a leitura só pode ser compreendida numa perspectiva crítica. Ler criticamente é admitir a pluralidade de interpretação, desvelar significados ocultos, resgatar a consciência do mundo, estabelecendo por meio dela uma relaçáo dialética com o texto" (4).

A leitura, assim, reveste-se de significado, possibilitando uma relaçáo dinâmica entre professor e aluno, onde ambos exercem alternadamente a função de sujeito sem sujeitar-se. $O$ sujeito-leitor interage com o texto, relaciona-se dinamicamente com ele, estabelece trocas, analisa, questiona, tornando-se capaz de selecionar dados significativos desta experiência. Só então ele terá condiçōes de posicionar-se criticamente.

"...a leitura do mundo precede sempre a leitura da palavra e a leitura desta implica a continuidade da leitura daquele (...) este movimento do mundo à palavra $\mathrm{e}$ da palavra ao mundo está sempre presente (...) a leitura da palavra não é apenas precedida pela leitura do mundo, mas por uma certa forma de "escrevế-lo" ou de "reescrevê-lo", quer dizer, de transformá-lo através de nossa prática consciente" (5).

A leitura enquanto "ato, arte ou hábito de ler" (6) transpóe os muros de origem da cidadela medieval - lectura - estendendo-se a todos os sentidos do homem: o que ele vê, ouve, fala, toca, cheira.

A Sala de Leitura/TV/Vídeo deve levar em conta esta extensão, abrigando e promovendo a informaçáo dos conhecimentos mais variados através de diferentes suportes (livro, vídeo, TV, rádio, etc.) num espaço outrora sacralizado como sede do conhecimento - a biblioteca - e que hoje vem assumindo um papel cada vez mais ativo e transformador.

Dentro deste contexto, as Salas de Leitura/TV/Vídeo ultrapassam o conceito tradicional das bibliotecas escolares, uma vez que devem constituir-se em "centros ativos de aprendizagem, nos quais os livros, em efetivo movimento, estarão associados a recursos plurissensoriais" (7).

As Salas de Leitura/TV/Vídeo devem permitir que seus usuários circulem no tempo e no espaço pelo patrimônio cultural da humanidade, seja movidos pelo interesse específico ou pelo prazer do conhecimento. Esta livre circulação pela informação leva o leitor a entrar em contato com as mais diferentes manifestaçóes do pensamento, o que conduz necessariamente ao conflito gerado por essas diferenças, à reflexão e à tomada de posição. 
"Toda biblioteca pública é permanentemente perigosa e, embora

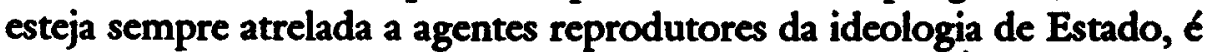
o espaço que mais pode subverter a produçáo cultural. É uma bombarelógio que pode explodir a qualquer momento, pois contém o elemento básico para a ação do indivíduo - a informação. Ao ordenar os registros do conhecimento humano, a biblioteca reúne discursos contraditórios e assim se torna uma fonte de conflitos, um ninho de desordem. Explode o dogmatismo de um conhecimento único muito próximo à fé e à verdade absoluta. Passa a incomodar as pessoas com o demônio das possibilidades múltiplas" (8).

Mas o espaço das Salas de Leitura/TV/Vídeo não deve ser apenas - lugar de acesso à produçáo cultural, mas também o lugar onde se produz cultura. Assim, deve ser um espaço onde se possa ver, ouvir, ler, escrever, dramatizar histórias, debater, trocar experiências, escrever o projeto para a produçáo de um vídeo ou para um programa de rádio, enfim, um espaço também de criação.

O livro, enquanto património cultural, exerce um papel de destaque nas Salas de Leitura/TV/Vídeo. O livro permite que o leitor caminhe no tempo e no espaço por toda a produçáo cultural acumulada, possibilita o contato com as mais variadas informaçóes e correntes de pensamento, levando o leitor a refletir, a rever posiçóes, a repensar o seu próprio pensamento.

"Nos meios de comunicação o jogo das contradiçōes até pode ser feito, como, por exemplo, uma emulaçăo de debates entre intelectuais ou através de jurados de programas populares, mas tais debates ou são estéreis e sem alcance para o público ou, de fato, sáo um teatro onde, no amplo palco do sistema econômico, debate-se como consumir e não por que consumir. Nenhum programa de televisão comercial questionará a sociedade de consumo e os seus valores. E se o fizer, será de tal forma que, no intervalo dé dois minutos, restauram-se todos os valores consumistas através dos comerciais" (9).

Nesta perspectiva, o livro se constitui no grande agente para o exercício de liberdade, para a fluidez do pensamento, para a problematizaçăo do homem e da vida, para o questionamento da ordem estabelecida e para a descoberta do novo.

O livro pode estabelecer com o leitor uma relaçāo lúdica, enquanto leitura recreativa; uma relação pedagógica, enquanto leitura informativa; e uma possibilidade de projeçăo, de reflexáo e de reconstrução do mundo, principalmente em se tratando do texto literário. Este, como expressão verbal e artística do escritor em seu momento de criaçáo, deixa 
transparecer seus valores, seus referenciais de classe social e sua posiçáo diante do mundo. Através da leitura, as experiências e valores contextuais do escritor se defrontam com os do leitor, instigando a reflexão deste, bem como permitindo o seu posicionamento crítico.

" $O$ ato de ler passa a ser, portanto, um processo contínuo de troca de experiências entre o autor $\mathrm{e} o$ leitor, ou seja, o leitor transfere para a leitura toda a sua carga experiencial ao analisar o texto e, ao mesmo tempo, usufrui das experiências do autor na compreensáo do seu mundo" (10).

Há que se ter cuidado de náo tornar a leitura do texto obrigatória, exigindo do aluno o preenchimento de fichas padronizadas e respostas estereotipadas. A leitura só é válida quando favorece o encontro de respostas significativas para o próprio leitor.

Além disso, entendemos que tudo que faz parte do contexto em que o homem vive é passível de leitura, sejam textos propriamente ditos, músicas, ilustraçóes, publicidades, enfim, tudo o que faz parte do mundo da significação e que estabelece uma comunicação. Desta forma, o sistema TV/Vídeo faz parte das atividades da Sala de Leitura, apesar de seu espaço físico diferenciado, podendo ser usado no auditório ou em uma sala reservada para tal atividade. Esta não deve se resumir na recepção passiva dos programas veiculados em canal aberto ou em sessóes de vídeo, mas como a oportunidade de ampliaçáo do acesso à informaçáo e a possibilidade de uma leitura crítica dos meios de comunicação de massa.

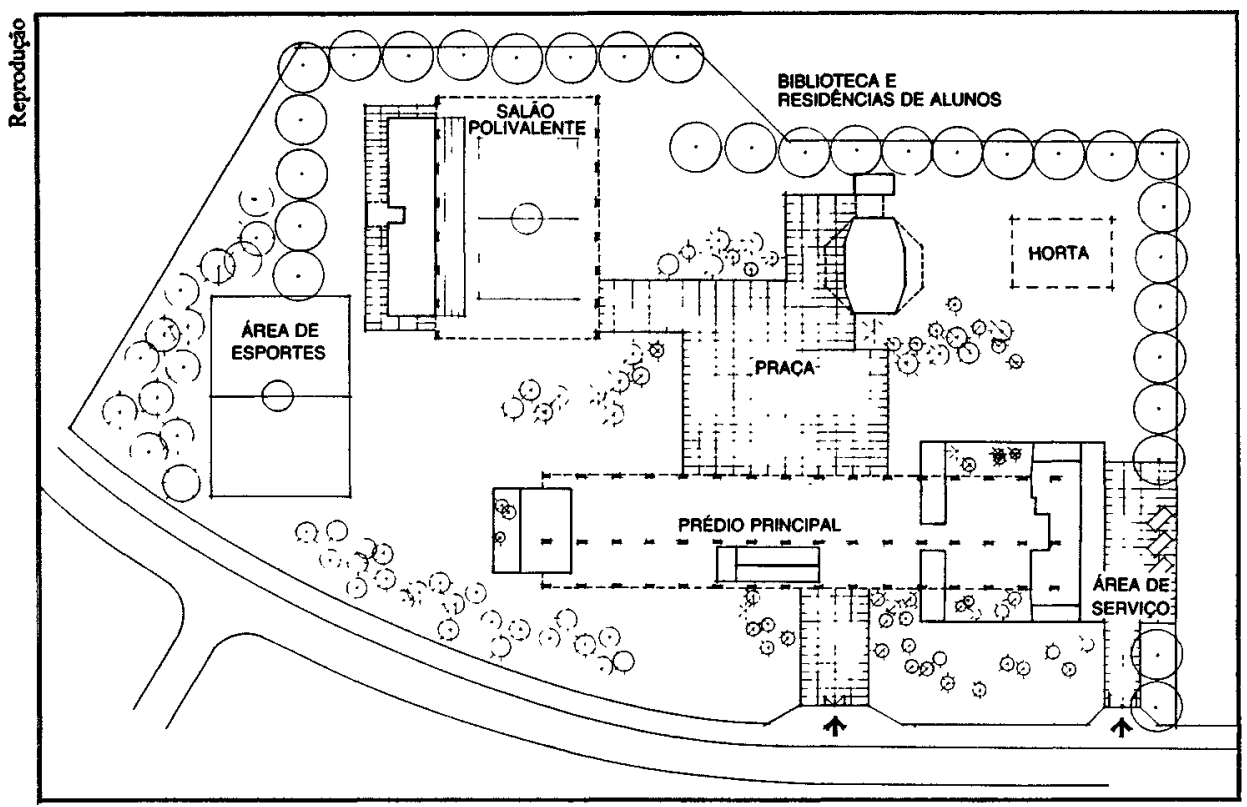

Projeto-padrão criado por Oscar Niemeyer para os CIEPs 


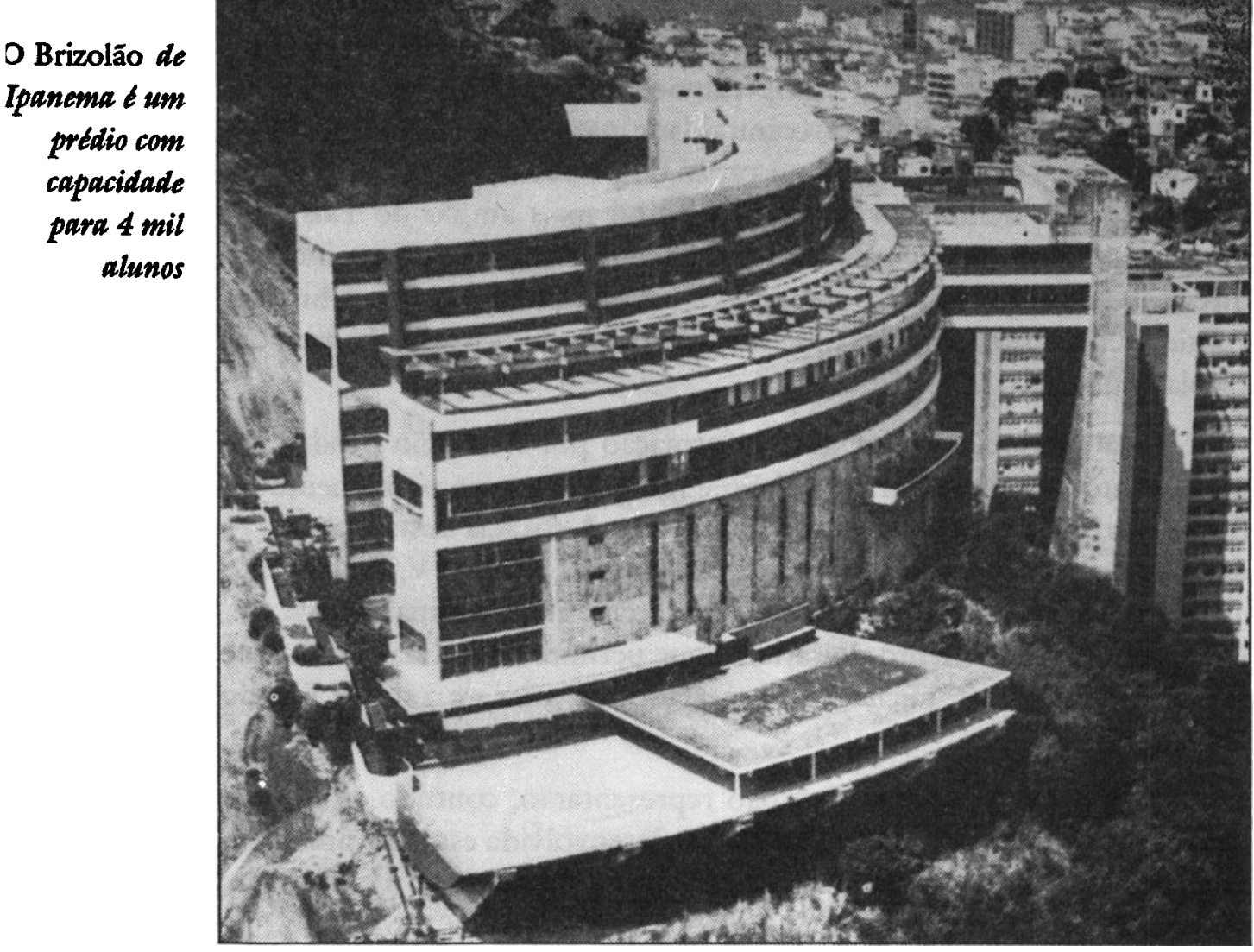

"Neste sentido, todo o trabalho desenvolvido deverá extrapolar seus aspectos mecânicos de recepçáo, gravação, reproduçăo de imagens para ser um momento de se ir "além da imagem", questionando a mensagem, descobrindo o como e o porquê agir e reagir a ela, sabendo a serviço de quem e de quê ela se apresenta, desvendando os "mistérios" da tecnologia, que vêm nos envolvendo num "mundo" polissêmico de imagens" (11).

É neste contexto que as Salas de Leitura devem cumprir seu objetivo amplo de difundir e ampliar os meios de aproximaçăo dos bens culturais à populaçáa, constituindo-se como centros ativos de produçáo cultural, nos quais os livros estarão associados a recursos plurissensoriais. É um espaço que deve atender não só aos alunos, àos professores e ao pessoal de apoio, como também à comunidade onde o CIEP está inserido. Ao cumprir esta dupla funçáo, elas se constituem em verdadeiros centros culturais, pois possibilitam aos seus usuários não só o acesso à produção cultural, como permitem que estes assumam o papel de agentes produtores de cultura, através do resgate e registro da me- 
mória local. O contato com a cultura erudita, a cultura popular e a cultura de massa náo deve excluir ou permitir o esquecimento da vivência daquela comunidade específica onde está localizado o CIEP. Ao contrário, o conhecimento e a compreensáo destas outras formas de expressáo cultural despertam a comunidade para uma leitura crítica da realidade que a cerca, tornando-a capaz de perceber, de se identificar e de se valorizar dentro do contexto cultural mais amplo do País. "É devolvendo o direito à palavra - e na nossa sociedade isto inclui o direito à palavra escrita - que talvez um dia possamos ler a história contida e não contada da grande maioria que hoje ocupa os bancos das escolas públicas" (12).

Qualquer veículo que gere informação por si só não produz conhecimento se não estiver articulado e integrado a uma permanente reflexão dos objetivos a que se propóe alcançar. A eficácia desta articulaçăo demanda o planejamento da equipe de Sala de Leitura/TV/Vídeo junto a todo o corpo docente, no sentido de se definir uma dinâmica de trabalho para o atendimento dos alunos que permita consolidar o hábito e o prazer pela leitura, iniciado e despertado nas salas de aula de Estudo Dirigido.

"As Salas de Leitura (...) não representaráo, contudo, apêndices das unidades escolares; a atividade nelas desenvolvida estará intimamente ligada à dos professores. As Salas trabalharáo com eles e não para eles ou isoladas deles" (13).

Há que se ter, no entanto, o cuidado de não transformar a Sala de Leitura/TV/Vídeo em mais uma sala de aula, com os conteúdos a serem assimilados e com toda a noģão de obrigatoriedade aí embutida. Queremos, com isso, dizer que as atividades da Sala de Leitura/TV/Vídeo não serão inseridas à grade curricular. Ela deve se caracterizar como espaço alternativo e complementar à sala de aula.

Sendo as Salas de Leitura/TV/Vídeo centros culturais voltados ao atendimento não só de alunos mas também de professores, funcionários de apoio, funcionários administrativos e comunidade em geral, deve oferecer opçóes de horários para 0 atendimento de todos esses segmentos. Assim, o seu funcionamento deverá ser o seguinte:

- atendimento à comunidade interna: durante o horário do funcionamento do CIEP, incluindo o horário do Projeto de Educaçáo Juvenil à noite;

- atendimento à comunidade externa: durante a semana, desde que não haja interferência no atendimento aos alunos, e nos fins de semana.

Para dar conta do atendimento a esta gama de usuários tão diver- 
sificados, as atividades a serem implementadas com os alunos no espaço da Sala de Leitura/TV/Vídeo estarăo ora em ebuliçăo, como um ambiente produtor de idéias, ora respeitando o silêncio necessário à leitura, como ato individual, interior e solitário, o que faz com que o mesmo texto nunca tenha a mesma leitura" (14).

\section{Estudo Dirigido}

Nos CIEPs, o que chamamos Estudo Dirigido tem uma perspectiva bem mais ampla do que o estudo individualizado, geralmente realizado por meio de módulos instrucionais muito em voga nos anos 70. Engloba uma série bastante variada e diversificada de atividades, envolvendo todos os conteúdos exphícitos e, muitas vezes, implícitos no currículo a serem realizados pelos alunos individualmente, em pequenos grupos e até, eventualmente, por todo o grupo em conjunto. Tais atividades têm por objetivo proporcionar aos alunos um momento para a realização, dentro da escola, de estudos e vivências pedagógicas dinâmicas que thes proporcionem oportunidades de desenvolver a independência, a curiosidade e o gosto pelo estudo, pela pesquisa, pela reflexão e pela crítica.

As crianças da classe média encontram numerosas oportunidades para praticar esse tipo de atividade em sua vida cotidiana: têm acesso com facilidade à bibliografia atualizada e diversificada, seus próprios pais e amigos orientam na realizaçăo de tarefas propostas pelos professores e propóem outras atividades culturais, muitas vezes dispóem de videocassete e, dentre suas atividades de lazer, são incluídos jogos de valor pedagógico; tudo isto de muita importância para sua formação. A grande maioria, senão a totalidade dos alunos dos nossos CIEPs, é proveniente das camadas menos favorecidas da populaçáo, que năo têm, disponíveis, esses recursos. Para eles, pesquisas e tarefas caseiras não proporcionam o mesmo crescimento e rendimento pedagógico que os mais favorecidos, pois se tornam tarefas solitárias e isoladas de um contexto cultural mais amplo. Por isso, a escola de horário integral se faz imprescindível para ampliar esse universo cultural e abrir novos horizontes. Torna-se da maior importância para a formaçáo desses alunos que possam contar, dentro da escola, com enciclopédias, dicionários, jornais, revistas, livros paradidáticos, jogos pedagógicos e, principalmente, com um professor que tenha por funçăo orientar suas pesquisas, esclarecer e aprofundar conteúdos que foram introduzidos na sala de aula e, sobretudo, propor atividades que permitam, ao mesmo tempo, aprofundar tais conteúdos e propiciar situaçōes de desafio à criatividade e raciocínio crítico de cada um. 
É necessário que se destinem salas especiais para o Estudo Dirigido equipadas com materiais variados para consultas, bibliografia recreativa, informativa e literária, jogos pedagógicos, etc. Os professores podem organizar o trabalho em forma de oficinas, realizando um rodízio dos grupos, ora propondo atividades que permitam superar dificuldades apresentadas por determinado aluno ou grupo de alunos, ora propondo atividades de enriquecimento a partir desses mesmos conteúdos. Cabe-lhes, também, orientar os alunos nas op̧̧óes pelas escolhas de leituras ou jogos e na confecção, pelos próprios alunos, de novos jogos e materiais que possam ser usados por todos. Convém ressaltar, também, que a proposta do Estudo Dirigido está intimamente ligada à Sala de Leitura/TV/Vídeo. Ao despertar no aluno o interesse pela pesquisa, pela descoberta do novo, pela consulta e pela leitura, facilitando as vias de acesso ao saber historicamente produzido e, desta forma, ampliando seu universo cultural, vincula-se ao projeto Salas de Leitura/TV/Vídeo, que poderá promover atividades integradas aos professores responsáveis pelo Estudo Dirigido, no sentido de permitir o aprofundamento e o desdobramento do que foi iniciado e despertado nas salas de aula e nas de Estudo Dirigido. Neste sentido, pode-se lançar máo de oficinas variadas, como, por exemplo, oficina do conto e da poesia, objetivando a produção do texto escrito; oficina a voz do rádio, objetivando o aperfeiçoamento da locução, da fluência e da criatividade.

Além disso, é muito comum que o aluno, uma vez despertado para um determinado assunto, procure espontaneamente a Sala de Leitura/ TV/ Vídeo, buscando o aprofundamento daquele tema. Também nestes casos é fundamental a integração entre a equipe de Sala de Leitura/ TV/ Vídeo e os regentes, pois é recomendável que a equipe das Salas esteja mobilizada para orientar nas opçóes de leitura sobre os principais temas que estáo sendo trabalhados nas salas de Aula ou de Estudo Dirigido. Por isso, é imprescindível que os coordenadores das Salas participem efetivamente nas Equipes Interdisciplinares. Caberá, também, às equipes das Salas o controle dos livros que, em rodízio, seráo utilizados nas salas de Estudo Dirigido.

Dessa forma, vê-se ser imprescindível que a ação do professor de Estudo Dirigido seja planejada com o conjunto do corpo pedagógico da escola, pois essas atividades se constituirão em momento privilegiado para o acompanhamento mais individualizado dos alunos, facilitando sua aprendizagem e superaçáo de dificuldades específicas, fornecendo dados valiosos para a avaliação do processo de construçáo do conhecimento de cada aluno em suas diversas etapas.

Educação Juvenil 
A Educação Juvenil tem como objetivo atender a população analfabeta e semi-analfabeta, na faixa etária compreendida entre 14 e 22 anos.

As razóes e as causas da existência de um grande contingente de jovens analfabetos das camadas mais pobres da população são várias $\mathbf{e}$ podem encontrar explicaçóes diversas dentro do sistema socioeconômico vigente no País e no próprio fracasso escolar. Sabemos que um número expressivo desses jovens já passou por esse sistema, que na maioria das vezes foi incapaz de alfabetizá-los plenamente. De um modo geral, as práticas pedagógicas desenvolvidas nas escolas não privilegiam as crianças das camadas menos favorecidas, pois estáo impregnadas pelos valores das classes dominantes da sociedade.

Em concordância com a filosofia dos CIEPs, a Educação Juvenil cria uma relação entre escola e alunos. Relação esta que deve ser de troca entre o saber universal e científico da escola e o saber produzido na luta cotidiana pela sobrevivência das camadas populares.

A Educação Juvenil está estruturada em dois blocos, sendo o primeiro destinado à alfabetização, entendida aqui como aquisição, pelo aluno, da capacidade de relacionar texto e contexto. Nesta primeira fase, temos a presença de diferentes áreas do conhecimento numa abordagem introdutória e interdisciplinar. No segundo bloco, as diferentes áreas do conhecimento passam a ser reveladas em suas especificidades, dando-se destaque ao instrumental próprio de cada ciência, favorecendo aos alunos a operacionalizaçáo desses conceitos, frente às necessidades do seu cotidiano.

A proposta da Educação Juvenil não determina um tempo rígido para que se possa alcançar os objetivos dos diferentes blocos, garantindo a total liberdade aos alunos de atingi-los de acordo com os seus diferentes ritmos de aprendizagem. Por conseguinte, nega-se a seriação, partindo-se do pressuposto que esta náo respeita a individualidade dos alunos.

Considerando que o traço novo do Programa de Educação Juvenil caracteriza-se por propor uma Escola totalmente diferente das tradicionais, a avaliação jamais poderá ser transformada num processo de controle do universo educacional. Um dos objetivos da Educação Juvenil é levar o aluno a tomar consciência de si e facilitar a formaçáo de sua identidade. A avaliação, assim, só poderá ser entendida como um momento de reflexáo e reelaboração da prática pedagógica, que deverá se realizar a partir de uma ação conjunta entre professor, aluno e comunidade.

Entendemos que a implantaçáo de uma proposta com tais carac- 
terísticas vem preencher a lacuna existente em relação à alfabetização de jovens.

\section{Animação Cultural}

O trabalho de Animaçáo Cultural cria uma ponte de mão dupla entre a escola e a vida comunitária.

No cotidiano dos CIEPs não é mais possível pensar a educaçáo como um momento prefixado na vida de cada pessoa: é necessário admiti-la como um processo dinâmico que acompanha os indivíduos por toda a vida, sendo impossível concebê-la dissociada de seu contexto cultural. A cultura irriga e alimenta a educaçáo que, por sua vez, é um excelente meio de transmissão da cultura.

Estruturado para agenciar uma nova síntese cultural, como elemento integrador de populaçōes marginalizadas à vida social digna, o CIEP se depara neste campo com um de seus maiores desafios: como desfazer o erro da escola tradicional, que relega aspectos culturais a plano secundário, chegando mesmo, em alguns momentos, a reduzir a cultura a meros eventos comemorativos ou de entretenimento? Mais do que isso, como instrumentalizar a clientela dos CIEPs para que ela alcance maior domínio do mundo?

Uma das respostas está no trabalho de Animação Cultural, que contribui para transformar a escola num espaço verdadeiramente democrático, integrando o processo educacional à vida comunitária e reunindo alunos, pais, vizinhos, artistas e professores numa dinâmica que soma a igualdade de oportunidade à consciência da desigualdade de condiçóes.

A Animaçáo Cultural é desenvolvida nos CIEPs como um processo conscientizador, que resgata o mais autêntico papel político e social da escola, através de um trabalho de organização, facilitação, estimulaçáo das práticas culturais em nível local, propondo-se a um espectro extremamente amplo de fazeres culturais. Dependendo do lugar, do tipo de instituição, do espaço no qual se trabalha e do tipo de clientela ou comunidade, das características socioeconômicas, políticas e culturais, $o$ conteúdo das açóes, que podem se chamar de Animaçáo Cultural, variará bastante.

Estabelece-se, conseqüentemente, a necessidade de animadores culturais em cada CIEP. Egressos de grupos de teatro, música, poesia, movimentos que se criam espontaneamente, de associaçóes comunitárias, esses profissionais trazem para o espaço escolar toda uma experiência que têm como instrumento de trabalho; dentre outros, a vivência do real e do imaginário, da emoção e do sensível. 
Cabe aos animadores fazer emergir, em cada CIEP, as cores e os tons da comunidade que circunda a escola: seja repentista ou a Folia de Reis, a banda de música ou o grupo de teatro, o sambista ou o escritor de cordel. Levando para o interior do CIEP produçóes das diferentes linguagens da cultura popular, os animadores criam uma estrada de mão dupla que favorece a erradicação de preconceitos e possibilita, a alunos e moradores locais, a identificação dos valores regionais e universais do produto cultural que receberam e, dos quais, muitas vezes sem perceberem, são co-autores.

Possuindo formaçóes diferenciadas, dominando linguagens diversas, estimulando a produçáo cultural, os animadores são as pessoaschave de todo o processo. São eles que possibilitam o desenvolvimento de atividades como a exibição de um filme para ser colocado em discussão, a realizaçáo de concertos, a promoção de exposiçóes (pintura, desenho ou fotografia), a montagem de espetáculos teatrais, a confeç̧ão de vídeos, a realizaçáo de oficinas de arte, a criaçăo de clubes ou associaçōes de alunos, a realizaçáo de jogos e brincadeiras, a promoģáo de festas comunitárias.

O trabalho da Animação Cultural deve ser feito em intensa articulaçáo com a açáo pedagógica, envolvendo todos os segmentos da escola e trazendo, para o cotidiano dos CIEPs, as diversas manifestaçóes culturais e artísticas, de modo a garantir uma efetiva participação das populaçóes locais. Dessa forma, os CIEPs atuam no sentido de resgatar o papel político-social da escola, no contexto de uma relaçáo mais estreita com a comunidade. É impossível dissociar a educação de seu conteúdo cultural. Assim, "educaçăo e cultura se interpenetram para compor uma verdadeira simbiose: a cultura irriga e alimenta a educaçáo que por sua vez é um excelente meio de transmissáo de cultura" (16).

\section{Alunos-residentes - algo inédito}

A Escola Pública convive, entre outros, com um problema crônico - a evasáo -, cuja causa reside, sobretudo, numa prática educativa construída sobre os alicerces da pedagogia da repetencia, que acaba por expulsar o aluno da escola, tão frequiente é o número de vezes em que ele se vê diante de mais uma reprovação. Evidentemente que se evadem as crianças oriundas das camadas menos privilegiadas da populaçăo, assim como sáo elas também que continuam sem matrícula na escola, ficando à margem do sistema escolar.

Segundo "levantamento do Laboratório Nacional de Computaçáo Científica (LNCC), o acesso à escola já está praticamente universalizado - 95\% de uma geraçăo entram. Falta no entanto - e esta parece 
ser a grande barreira a ser transposta pelo governo - manter $o$ aluno estudando".

Pelos dados do LNCC, a criança entra na escola e nela permanece tempo suficiente para cumprir todo o $1^{\circ} \mathrm{grau}-\mathrm{sem}$, no entanto, chegar à $4^{a}$ série. As sucessivas repetências - um índice de $50 \%$ da $1^{a}$ para a 2a série -, causadas pela baixa qualidade do ensino, entravam seu caminho. Se quase toda uma geração entra na escola, apenas $40 \%$ dela chegam à $8^{\mathrm{a}}$ série $(17)$.

A partir desta realidade, o Projeto Alunos-Residentes constitui-se em mais um dos instrumentos do Programa Especial de Educação contra a evasão escolar, fenômeno com o qual convivemos até hoje e de forma tão impotente. $O$ projeto terá seu efeito mais vigoroso se vier a contribuir, efetivamente, para que a escola assuma a sua destinaçăo social, a todos chamando e a ninguém excluindo. Ao invés de expulsar aquele aluno que inicia seu processo de evasão, a escola o apóia, através do encaminhamento à residência do CIEP e do trabalho social com seu familiar, na busca de caminhos para superar o problema existente. No caso das crianças abandonadas ou em estágio de pré-marginalização, 0 projeto funciona como instrumento de inserção da criança no sistema escolar, buscando também, e principalmente, a repersáo, isto é, o retorno dos alunos-residentes a sua própria família.

Nesse sentido, o trabalho é, acima de tudo, educacional e, assim, tem cunho social. As atividades desenvolvidas pelo Projeto AlunosResidentes não podem ser confundidas, de forma alguma, com práticas assistencialistas, pois que náo se trata de um internato, nem de uma creche pura e simples.

No alto edifício principal ou sobre a biblioteca de cada CIEP, existem moradias para abrigar crianças desamparadas, que são assistidas por um casal-residente especialmente treinado para essa missão. $O$ atendimento é restrito a um número máximo de 24 alunos por CIEP, aos cuidados de um casal para cada grupo de doze crianças, que estấo na faixa de 6 a 14 anos. Durante sua permanência, os alunos-residentes inserem-se nas atividades escolares de rotina, a partir das 8 horas, recolhendo-se às residências do CIEP ao fim do dia. Nos finais de semana, feriados e férias escolares, esses alunos, sempre que possível, voltam à convivência com seus pais ou responsáveis, de modo a evitar que se rompam os laços familiares.

A rotatividade de atendimento, prevista pelo Projeto, torna imprescindível a conscientizaçáo de diretores, professores, casais-residentes, familiares e, sobretudo, das próprias crianças atendidas, o que evi- 
dencia o caráter político-social do trabalho a ser desenvolvido.

"O Projeto Alunos-Residentes não pretende resolver o grave problema social da criança carente e marginalizada, mas certamente permitirá retirar da experiência cotidiana novas e produtivas formas de tratar a questão" (18).

\section{Notas}

1 RIBEIRO, Darcy. Lipro dos CIEP, Rio de Janeiro, Bloch ed., 1986, p.12.

2 Idem, p.13.

3 Idem, p.13.

4 SANTOS, Maria Ribeiro. "A leitura recreativa no 19 grau", in Revista A MAE, Belo Horizonte, Universidade Federal de Minas Gerais, 1989, p.39.

5 FREIRE, Paulo. A importacia do ato de lor, Såo Paulo, Cortez, 1989, p.20.

6 HOLANDA, Aurelio Buarque de. Nopo diciontrio da Ungua poranguesn, Rio de Janeiro, Nova Fronteira, 1988, p.1019.

7 Falas no professor. Rio de Janeiro, PEE - Programa Especial de Educaçao, p.31.

8 MILANEZI, Luis. Desordenar para ordenur, Sxo Paulo, Brasiliense, 1989, contracapa.

9 Ideam, p.255.

10 SANTOS, Maria Ribeiro dos. op. cit., p.39.

11 Relat frio do grupo de trabalbo sala de leiturafoldeo, Rio de Janeiro, Secretaria Municipal de Educação, 1989, p.11.

12 GERALDI, Joăo Wanderley. cf. RIBEIRO, Darcy. op. cit., p.63.

13 RIBEIRO, Darcy. Op. cit., p.125.

14 Relatorio do grupo de traballso sala de leiturafridteo. op. cit., p.9.

15 RIBEIRO, Darcy. " Política cultural do Rio de Janeiro; animaçáo cultural agora é patrimônio público" in Revista do Brasil Rio de Janeiro, 1986.

16 RIBEIRO, Darcy. Livro dos CIEPs, Rio de Janeiro, Bloch, 1986, p.133.

17 Jornal do Brasil, Rio de Janeiro, 18 de agosto de 1991, $1^{2}$ caderno, p.18

18 RIBEIRO, Darcy. Op. cit., p.7. 